\title{
Interspecific barriers between salmonids when hybridisation is due to sneak mating
}

\author{
E Garcia-Vazquez ${ }^{1}$, P Moran², J Perez ${ }^{1}$, JL Martinez ${ }^{1}$, JI Izquierdo ${ }^{1}$, B de Gaudemar ${ }^{3}$ and E Beall ${ }^{3}$ \\ ${ }^{1}$ Departamento de Biologia Funcional, Universidad de Oviedo. C/ Julian Claveria s/n. 33006-Oviedo, Spain; ${ }^{2}$ Departamento de \\ Bioquimica, Xenetica e Inmunoloxia, Universidad de Vigo. Facultad de Ciencias, Campus Lagoas-Marcosende, 36200-Vigo, Spain; \\ ${ }^{3}$ Ecologie Comportementale des Poissons, INRA Unité de Recherches en Hydrobiologie, BP 3, 64310 Saint Pée sur Nivelle, France
}

Male sneaking behaviour can lead to interspecific hybridisation if sneakers attempt to fertilise ova in heterospecific mating, contributing to break down of interspecific barriers. In south European rivers, sneaking Atlantic salmon males fertilise an important proportion of ova from adult females in heterospecific crosses, up to $65 \%$. In a south French flow- controlled stream, we found that they were able to naturally fertilise brown trout ova in absence of brown trout males. Aggressiveness of brown trout males towards sneaking salmon males and low survival of hybrids issued from salmon sneakers are found to be interspecific barriers.

Heredity (2002) 89, 288-292. doi:10.1038/sj.hdy.6800134

Keywords: Atlantic salmon; brown trout; interspecific hybridisation; sneaking behaviour

\section{Introduction}

Alternative male mating strategies and tactics are described for very different animal taxa. Some examples can be found in mammals (Gemmell et al, 2001), birds (Pitcher and Stutchbury, 2000), crustaceans (Shuster and Sassaman, 1997), anurans (Lucas and Howard, 1995), insects (Thomkins and Simmons, 2000) and all the range of poikylotherms (for a good revision see Journal of Heredity 92 (2), 2001). Males can adopt different behaviour patterns with differential reproductive success. Fish species are not an exception. Salmonids (Gross, 1985, 1996), Blennioids (Neat, 2001), Poecilids (Pilastro and Bisazza, 1999) and other fish taxa exhibit very diverse male mating behaviour that vary from actively courting of the female to furtively release sperm when a female is courted by other males (sneaking). Small young Atlantic salmon males (called mature parr) which mature in the river before migrating to the sea exhibit a typical sneaking behaviour with a high fertilisation success in the wild (Martinez et al, 2000). At the southern edge of their geographical distribution, almost all Atlantic salmon males mature before seaward migration because freshwater maturation is enhanced by higher temperatures (Rowe and Thorpe, 1990; Prévost et al, 1992). The rapid growth of juveniles in rivers leads to parr maturity in the first or second year of life, both in North America (Letcher and Terrick, 1998) and Europe (Utrilla and Lobon-Cervia, 1999). Up to $80 \%$ of the male parr may mature in some rivers (Héland and Dumas, 1994; Nicieza and Braña, 1995). As a consequence, the contribution of sneaking males to the gene pool of southern wild populations is

Correspondence: E Garcia-Vazquez. Departamento de Biologia Funcional, Universidad de Oviedo. C/ Julian Claveria, s/n. 33006-Oviedo, Spain. E-mail address: egv@sauron.quimica.uniovi.es

Received 7 January 2002; accepted 29 May 2002 very important; they increase population size (Myers, 1984; L'Ábée-Lund 1989), which maintains genetic variability (Garcia-Vazquez et al, 2001).

Atlantic salmon (Salmo salar L.) and brown trout ( $S$. trutta L.) are sympatric species in western Europe, from Norway to northern Spain. Hybrids of Atlantic salmon and brown trout are found in the wild over the range of distribution of both species. In surveys of European rivers, hybridisation rates ranged from 0.1 to $13 \%$ (Verspoor, 1988; Jansson et al, 1991). The maternal species has been determined in a few cases. In hybrids from European rivers the mother was Atlantic salmon in some cases (Youngson et al, 1992, 1993; Garcia-Vazquez et al, 2001) and brown trout in others (Hartley, 1996; Jansson and Ost, 1997). American wild hybrids were reported to be the product of a cross between female brown trout and male Atlantic salmon (McGowan and Davidson, 1992a; Gephard et al, 2000).

It is thought that alternative male mating behaviour can promote interspecific hybridisation, and break down interspecific barriers. Alternative male behaviour patterns such as sneaking, takeover and interception lead to cross-mating between Mnais damselfly species (Nomakuchi and Higashi, 1996). Natural hybridisation among distant members of Bufo toad species may be due to alternative mating tactics of males (Gergus et al, 1999). For fish species, although there is a considerable number of studies on alternative male mating strategies, this point has been rarely addressed. Between species male parasitic spawning has been described in Axoclinus triplefin blenny fish (Neat, 2001). Hybrids issued from brown trout mother were sampled in river areas where sneaker Atlantic salmon males are present (Elo et al, 1995; Jansson and Ost, 1997; Gephard et al, 2000). This suggests that the sneaking behaviour of small Atlantic salmon males is responsible for interspecific hybridisation between Atlantic salmon and brown trout. However, clear experimental 
evidence for such interspecific crosses being due to sneaking Atlantic salmon does not currently exist.

In this work we investigated the role of mature parr in the hybridisation between Atlantic salmon and brown trout at the southernmost latitude of the distribution of Atlantic salmon in western Europe $\left(43^{\circ} \mathrm{N}\right)$. In rivers flowing into the Bay of Biscay from northern Spain and southern France, where most Atlantic salmon parr mature in freshwater, hybrids issued from sneaking Atlantic salmon are likely to occur. However, all juvenile and adult hybrids found in the wild were offspring of Atlantic salmon females in this area (Beall et al, 1997; Garcia-Vazquez et al, 2001), contrarily to what would be expected if sneaker salmon contributed to interspecific hybridisation. We investigated possible interspecific barriers in a controlled stream, where mature individuals of both species in different situations were released.

\section{Materials and methods}

\section{Experimental procedures}

Experiments were conducted in a controlled-flow channel diverted from the Lapitxuri stream, a tributary of the River Nivelle (see Beall and de Gaudemar, 1999, for a description of the site and experimental installations). Wild mature individuals of both species, caught by trapping or electrofishing in the Nivelle, were measured and weighed, and scales sampled for age determination. Adipose fins were clipped for DNA analyses; and simultaneaously placed in separate, $30 \mathrm{~m}^{2}$ sections of the channel where they could spawn without any human interference. All the animal manipulation was made in large circular tanks ( $2 \mathrm{~m}$ diameter) full of well oxigenated river water, under effect of anaesthetics 2-P-E at the standard doses. Animal suffering and stress was avoided in each step of the experimental manipulation, keeping animals anaesthetised and handling them carefully. The experiments did not result in animal mortality in any case. To avoid detraction of many breeders from the wild population, we limited our experimental design by reducing the number of replicates. Scale and fin tissue sampling is not agressive for salmon in any way and do not represent any risk for their survival. Behavior is not affected by this tissue sampling.

Table 1 presents the experimental design. To homogenise as much as possible the experimental situations, all Atlantic salmon adults (AS) were grilse (anadromous individuals returning to the river after 1 year in the sea). Much smaller mature Atlantic salmon males (Atlantic salmon parr, ASP) were 1 or 2-year-old. Brown trout (BT) males and females were of different ages (and subsequently of different sizes), depending on the experimental situation. We designed three control conspecific situations with only brown trout (A, B and $\mathrm{C}$ ) involving a total number of 16 females and 22 males. Interspecific situations with sneaking salmon males without possibility of mate choice (allospecific males) were D, E and $\mathrm{F}, \mathrm{F}$ including also a larger anadromous salmon male. Interspecific situations with possibility of mate choice (both sneaker allospecific and conspecific males) were $G$ and $\mathrm{H}$.

To compare the survival of hybrids issued from brown trout mother with that of hybrids issued from the reciprocal cross, we prepared two experimental situations involving one AS female and one BT male: I and J. Two conspecific situations with Atlantic salmon females and sneaker mature parr were also prepared ( $\mathrm{K}$ and $\mathrm{L}$ ).

Spawning activity was directly observed and recorded with an Ikegami low light surveillance camera.

\section{Survival estimate}

At the end of each experiment, ie, when no more spawning activity was observed, fish were removed and the females were gently stripped by pressing on the abdominal cavity to express any remaining eggs (to determine egg retention). Egg retention was deduced from the estimated fecundity of each female. The number of ova or absolute fecundity $\mathrm{F}$ is given by the relation $\mathrm{F}=1689.9$ $\mathrm{W}^{1.1046}$, where $\mathrm{W}$ is female weight in $\mathrm{kg} ; r^{2}=0.83, n=85$; Beall and de Gaudemar, 1999) to estimate the number of eggs deposited. Survival of progeny of each section (egg survival to the fry stage) was estimated by the ratio of the number of fry recovered after emergence to the estimated total number of eggs deposited in that section.

Fertilisation of ova in all sections was confirmed by carefully open the redds (nests) and checking the presence of living eggs some weeks after spawning. Eyed eggs were sampled from redds in the experimental channel and alcohol-preserved for genetic analysis. The rest of the offspring remained in the channel to determine fry survival in each experimental situation. Fry were captured either by trapping during the first dispersal after yolk sac absorption and emergence, with modified fyke nets placed at the end of each section, or by electrofishing. In the D and F situations survival was very low and all the emerging individuals were ethanol-preserved for genetic analyses.

\section{Genetic analysis}

Two diagnostic loci were employed for species identification: the 5S rRNA genes and the restriction pattern of the histone genes. A portion of the adipose fin was used for extracting DNA. Total DNA extraction was carried out according to Taggart et al (1992). PCR analysis of the 5S rDNA was carried out following Pendas et al (1995) and restriction analysis of the histone genes followed Perez et al (1999).

For identification of offspring of small sneaking males when a large salmon male is present (situation F), we have carried out paternity analysis employing VNTR loci (Martinez et al, 2000).

\section{Results}

Table 2 presents the results of the experiments carried out in the Lapitxuri channel. Hybrids issued from Atlantic salmon sneaker males were obtained only in absence of conspecific males (situations D, E and F). By direct observation, as well as analysing the videotapes recorded, we found that the behaviour of mature salmon parr was always sneaking in all the three situations. Salmon parr remained hidden behind stones waiting for the moment of oviposition for rapidly approaching the female and releasing sperm. As expected, all the offspring recovered in these three sections of the experimental channel presented genotypes corresponding to hybrids, for both $5 S$ rRNA and histone gene markers analysed: one gene variant of $S$. salar and one gene variant of $S$. trutta. In the situation $\mathrm{F}$ the large salmon male did 
Table 1 Experimental situations prepared in the controlled stream

\begin{tabular}{|c|c|c|c|}
\hline Situation & Type & Females & Males \\
\hline \multicolumn{4}{|c|}{ (a) Brown trout females } \\
\hline A & Control BT & 5 BT $(28.5-221 \mathrm{~g}, 13.3-26.4 \mathrm{~cm})$ & $\begin{array}{c}6 \text { BT }(27.8-117.6 \mathrm{~g}, \\
13.4-21.8 \mathrm{~cm})\end{array}$ \\
\hline $\mathrm{B}$ & Control BT & 5 BT $(93-690 \mathrm{~g}, 20.9-40 \mathrm{~cm})$ & $\begin{array}{l}10 \text { BT }(30.8-612.2 \mathrm{~g}, \\
14.2-39.8 \mathrm{~cm})\end{array}$ \\
\hline $\mathrm{C}$ & Control BT & 7 BT (123.1-724.6 g, 22.3-43.4 cm) & $\begin{array}{c}6 \text { BT }(39.1-1119.5 \mathrm{~g}, \\
15.3-49.5 \mathrm{~cm})\end{array}$ \\
\hline $\mathrm{D}$ & Heterospecific - no choice & 5 BT $(180-430 \mathrm{~g}, 24-35 \mathrm{~cm})$ & $\begin{array}{l}6 \text { ASP }(5-17 \mathrm{~g} \\
6.5-9.8 \mathrm{~cm})\end{array}$ \\
\hline $\mathrm{E}$ & Heterospecific - no choice & 5 BT (44.2-166.4 g, 15.4-24 cm) & $\begin{array}{l}6 \text { ASP }(9-32.9 \mathrm{~g} \\
8.9-13.7 \mathrm{~cm})\end{array}$ \\
\hline $\mathrm{F}$ & Heterospecific - no choice & 5 BT $(90-280 \mathrm{~g}, 20-28.5 \mathrm{~cm})$ & $\begin{aligned} & 1 \text { AS }(2190 \mathrm{~g}, 66.3 \mathrm{~cm}) \\
+ & 6 \text { ASP }(5-15 \mathrm{~g}, 7-11.5 \mathrm{~cm})\end{aligned}$ \\
\hline G & Heterospecific - choice & 5 BT $(67-236 \mathrm{~g}, 17.7-27 \mathrm{~cm})$ & $\begin{aligned} & 6 \text { ASP }(7.5-23.9 \mathrm{~g}, 8.4-13.5 \mathrm{~cm}) \\
+ & 6 \text { BT }(19.3-108.5 \mathrm{~g}, 12.1-21.5 \mathrm{~cm})\end{aligned}$ \\
\hline $\mathrm{H}$ & Heterospecific - choice & 5 BT $(46.8-255 \mathrm{~g}, 15.7-27.4 \mathrm{~cm})$ & $\begin{array}{l}6 \text { ASP }(23.8-40.8 \mathrm{~g}, 12.8-15.8 \mathrm{~cm}) \\
+6 \text { BT }(29.2-112.2 \mathrm{~g}, 13.4-23.3 \mathrm{~cm})\end{array}$ \\
\hline \multicolumn{4}{|c|}{ (b) Atlantic salmon females } \\
\hline I & Heterospecific - no choice & 1 AS $(2330 \mathrm{~g}, 64.5 \mathrm{~cm})$ & $1 \mathrm{BT}(1845 \mathrm{~g}, 56.8 \mathrm{~cm})$ \\
\hline J & Heterospecific - no choice & 1 AS $(2380 \mathrm{~g}, 62.9 \mathrm{~cm})$ & 1 BT $(424 \mathrm{~g}, 34.3 \mathrm{~cm})$ \\
\hline $\mathrm{K}$ & Control AS & 1 AS $(2325 \mathrm{~g}, 64.9 \mathrm{~cm})$ & 6 ASP $(5-35 \mathrm{~g}, 7-13.5 \mathrm{~cm})$ \\
\hline $\mathrm{L}$ & Control AS & 1 AS $(2370 \mathrm{~g}, 65.2 \mathrm{~cm})$ & 6 ASP $(5-10 \mathrm{~g}, 7-10.5 \mathrm{~cm})$ \\
\hline
\end{tabular}

$\mathrm{BT}=$ brown trout; AS = Atlantic salmon (anadromous); ASP = Atlantic salmon (mature parr). In parentheses, weight $(\mathrm{g})$ and length $(\mathrm{cm})$ of the individuals employed as parentals.

Table 2 Results of hybridisation experiments in the Lapitxuri controlled flow channel

\begin{tabular}{|c|c|c|c|c|c|}
\hline Situation & Type & $\begin{array}{l}\text { Interspecific } \\
\text { courtship }\end{array}$ & $\begin{array}{l}\text { Aggressive } \\
\text { behaviour }\end{array}$ & $\begin{array}{c}\text { Fry survival } \\
\%\end{array}$ & $\begin{array}{c}\text { Number of } \\
\text { offsprings typed }\end{array}$ \\
\hline \multicolumn{6}{|c|}{ (a) Brown trout female } \\
\hline A & Control BT & - & - & 59.7 & - \\
\hline $\mathrm{B}$ & Control BT & - & - & 74.7 & - \\
\hline $\mathrm{C}$ & Control BT & - & - & 10.7 & - \\
\hline $\mathrm{D}$ & Heterospecific - no choice & Sneaking & No & 1.3 & $18 \mathrm{H}$ \\
\hline $\mathrm{E}$ & Heterospecific - no choice & Sneaking & No & 0 & $11 \mathrm{H}$ \\
\hline $\mathrm{F}$ & Heterospecific - no choice & Sneaking & No & 1.96 & $9 \mathrm{H}$ \\
\hline G & Heterospecific - choice & No & BT males to ASP & 40.2 & $100 \mathrm{BT}$ \\
\hline $\mathrm{H}$ & Heterospecific - choice & No & BT males to ASP & 70.6 & $100 \mathrm{BT}$ \\
\hline \multicolumn{6}{|c|}{ (b) Atlantic salmon female } \\
\hline I & Heterospecific - no choice & Yes & No & 26.6 & $100 \mathrm{H}$ \\
\hline $\mathrm{J}$ & Heterospecific - no choice & Yes & No & 33.3 & $79 \mathrm{H}$ \\
\hline $\mathrm{K}$ & Control AS & - & - & 16.1 & - \\
\hline $\mathrm{L}$ & Control AS & - & - & 15.5 & - \\
\hline
\end{tabular}

$\mathrm{BT}=$ Brown trout; $\mathrm{ASP}=$ Atlantic salmon parr; $\mathrm{AS}=$ Atlantic salmon; $\mathrm{H}=$ hybrid.

not participate in reproduction. Paternity analyses demonstrated that the nine survivor hybrids were offspring of two or three mature parr, not of the adult male.

In presence of brown trout males (situations $\mathrm{G}$ and $\mathrm{H}$ ), sneaker Atlantic salmon parr were not able to fertilise brown trout ova. Analyses of video records and direct observation of the reproductive behaviour showed that the aggressiveness of brown trout males towards sneaking Atlantic salmon prevented any success of ova fertilisation by sneakers. All the offspring recovered was genetically pure $S$. trutta.

Egg survival until fry stage was very variable among situations. In conspecific crosses it ranged from 10.7 (C) to 74.7 (B). Survival of hybrids was extremely low (0$1.95 \%$, situations D-F), significantly different from fry survival of pure brown trout in the same experimental conditions (Contingency Chi-square 180.02 with $P<0.001$ ).

Hybrids of Atlantic salmon females and brown trout males (Table 2, situations I and J) were obtained by a typical courtship behaviour between the trout male and the salmon female. The directly observed and video recorded courtship pattern included, as in the case of anadromous salmon males with salmon females (de Gaudemar and Beall, 1999), repeated sequences of male quivering, crossover and swimming around the female followed by female digging into the substrate to prepare the nest. Direct observation and video records evidenced that male trouts did not adopt sneaking behaviour in any case. As expected, all the offspring recovered in the two 
channel sections was genetically hybrid of $S$. salar and $S$. trutta. Mean survival at fry emergence was $29.1 \%$. Moved into farm conditions they were able to reach their third year of age.

When salmon females reproduced with sneaker conspecific males (situations $\mathrm{K}$ and $\mathrm{L}$ ), fry survival average was $15.8 \%$, significantly higher than fry survival of hybrids issued from sneaker salmon (Chi-square 170.17 with $P<0.001$ ).

\section{Discussion}

We demonstrate that interspecific hybrids can be obtained by sneaking behaviour of Atlantic salmon parr. However, their survival was extremely low in the experimental stream (0-1.95\%), much lower than the survival of pure brown trout. Could the poor survival we found for hybrids obtained from brown trout females be attributed to the fact that they were offspring of mature male parr, not of adult salmon? Artificial breeding experiments have shown that sperm of mature parr and anadromous salmon do not differ in their capacity to fertilise eggs successfully and to produce viable offspring in conspecific crosses (Thorpe and Morgan, 1980). Our results obtained in the Lapitxuri stream clearly show that the survival of pure Atlantic salmon offspring of mature male parr is much higher than the survival of interspecific hybrids offspring of this type of males, therefore the poor survival of the hybrids is derived from the cross interspecificity. It is a interspecific barrier and not to a poor survival of mature male parr offspring per se.

The survival of hybrids naturally produced with Atlantic salmon sperm and brown trout ova was much lower than the survival of hybrids obtained by fertilisation of Atlantic salmon ova under the same experimental conditions (around 30\%). There are no clear results about the relative viability of the reciprocal hybrids of Atlantic salmon and brown trout in breeding experiments carried out in farm conditions. Some showed higher survival of hybrids produced from trout eggs (Refstie and Gjedrem, 1975) whereas other reported a greater success with hybrids produced using salmon eggs (Piggins, 1970; McGowan and Davidson, 1992b). Results from these experiments probably depend on the particular strains used in the cross and on gamete quality at the time of fertilisation (Chevassus, 1979).

Our experiments at the Lapitxuri stream unequivocally demonstrate that sneaking behaviour leads to hybridisation between Atlantic salmon and brown trout. Hybrids were obtained from brown trout females and sneaking mature male parr. This confirms by first time that alternative male mating behaviour allows interspecific hybridisation in salmonids, as suggested by Elo et al (1995), Jansson and Ost (1997) and Gephard et al (2000) from field observations, and by Olsén et al (2000) from the potency of heterospecific stimuli in endocrine responses in male parr. Similar results were obtained in other taxa: insects (Nomakuchi and Higashi, 1996), anuran (Gergus et al, 1999) and also other fish (Neat, 2001). Following this rationale, the species in which males adopt sneaking mating strategies will more probably provide the male in interspecific crosses with the species in which males present only one mating strategy than the reverse. Are hybrids issued from $S$. salar sneaker males and S. trutta

females more frequent than the reciprocal hybrids in south European rivers?

The answer is certainly not. Previous results on hybrid surveys in south European rivers revealed that none of the many hybrids found in wild could be the product of a cross of a brown trout female and an Atlantic salmon male. Analysis of mitochondrial DNA demonstrated that they were always offspring of Atlantic salmon females (Beall et al, 1997; Garcia-Vazquez et al, 2001). Therefore the contribution of Atlantic salmon mature male parr to interspecific hybridisation, if existing in southern Europe, was very low or negligible. However, they should exist because mature parr are very abundant in these rivers (Héland and Dumas, 1994; Nicieza and Braña, 1995; Utrilla and Lobon-Cervia, 1999). The existence of this type of hybrids in the wild has been proved unambiguously in North American rivers (Gephard et al, 2000). Our results show that, although in a very small proportion (around 1\%), these hybrids can survive until dispersion from nest. But we have found another interspecific barrier: the aggressiveness of brown trout males towards sneaking male parr. This pre-mating barrier works obviously only in presence of brown trout males. It is difficult to overcome by male parr in south European rivers because brown trout populations are very abundant (Reyes-Gavilan et al, 1996). Therefore there are always brown trout males around mature females to eventually attack sneaking Atlantic salmon mature males and consequently there are few chances to produce hybrids. It is logical to suppose that hybrids derived from sneaker Atlantic salmon parr exist, although in a so low rate that their detection is very difficult in random surveys, even if thousands of individuals are sampled.

In conclusion, we have found that interspecific S. salar $\times S$. trutta hybrids are produced by sneaking behaviour of Atlantic salmon males. Although sneaking behaviour leads to a breakdown of pre-mating interspecific barriers, other pre- and post-mating interspecific barriers existing between these two species (aggressiveness of trout males, low survival of hybrids) counteract the effect of such breakdown and most probably avoid significant increases of hybridisation rate in south European rivers.

\section{Acknowledgements}

We are indebted to Stephan Glise (INRA, St Pee sur Nivelle, France) and to the Nivelle Fishermen Association and INRA staff, from France, for collaborating in sampling tasks. Dr Francis Juanes (University of Massachusetts) kindly revised the manuscript. This work was finantially supported by the Spanish DGICYT HF1997-0215, DGICYT PB98-1570, and by the French INRA-Region Aquitaine contract 940308004 and Integrated Action 93187.

\section{References}

Beall E, De Gaudemar B (1999). Plasticite de comportements chez le saumon Atlantique (Salmo salar) en fonction des conditions environmentales. Cybium 23: 9-28.

Beall E, Moran P, Pendas AM, Izquierdo JI, Garcia-Vazquez E (1997). Hybridization in natural populations of salmonids in south-west Europe and an experimental channel. Bulletin Français de la Pêche et la Pisciculture 344/345: 271-285.

Chevassus B (1979). Hybridization in salmonids: results and perspectives. Aquaculture 17: 113-128. 
De Gaudemar B, Beall E (1999). Reproductive behavioural sequences of single pairs of Atlantic salmon in an experimental stream. Animal Behaviour,57: 1207-1217.

Elo K, Erkinaro J, Vuorinen A, Niemela E (1995). Hybridisation between Atlantic salmon (Salmo salar) and brown trout (Salmo trutta) in the Teno and Naatamo River systems, northernmost Europe. Nordic J Freshwater Res 70: 56-61.

Garcia-Vazquez E, Moran P, Martinez JL, Perez J, De Gaudemar B, Beall E (2001). Alternative mating strategies in Atlantic salmon and brown trout. J Hered 92: 146-149.

Gemmell NJ, Burg TM, Boyd IL, Amos W (2001). Low reproductive success in territorial male Anctarctic fur seals (Arctocephalus gazella) suggests the existence of alternative mating strategies. Mol Ecol 10: 451-460.

Gephard S, Moran P, Garcia-Vazquez E (2000). Evidence of successful natural reproduction between brown trout and mature male Atlantic salmon parr. Trans Am Fish Soc 129: 301-306.

Gergus EWA, Malmos KB, Sullivan BK (1999). Natural hybridisation among distantly related toads (Bufo alvarus, Bufo cognatus, Bufo woodhousii) in Central Arizona. Copeia 199: 281-286.

Gross MR (1985). Disruptive selection for alternative life histories in salmon. Nature 313: 47-48.

Gross MR (1996). Alternative reproductive strategies and tactics: diversity within sexes. Trends Ecol Evol 11: 92-98.

Hartley SE (1996). High incidence of Atlantic salmon x brown trout hybrids in a lake district stream. J Fish Biol 48: 151-154.

Héland M, Dumas J (1994). Ecologie et comportement des juveniles. In: Gueguen J, Prouzet P (eds) Le saumon atlantique, biologie et gestion de la ressource, Editions de l'IFREMER: Brest. pp $29-46$.

Jansson H, Holmgren I, Wedin K, Andersson T (1991). High frequency of natural hybrids between Atlantic salmon, Salmo salar L., and brown trout, S. trutta L., in a Swedish river. J Fish Biol, 39(A): 343-348.

Jansson H, Ost T (1997). Hybridisation between Atlantic salmon (Salmo salar) and brown trout (Salmo trutta) in a restored section of the River Dalalvan, Sweden. Can J Fish Aquat Sci 54: 2033-2039.

L'Abée-Lund JH (1989). Significance of mature male parr in a small population of Atlantic salmon (Salmo salar). Can J Fish Aquat Sci 46: 928-931.

Letcher BH, Terrick TD (1998). Maturation of male age-0 Atlantic salmon following a massive, localized flood. J Fish Biol 53: 1243-1252.

Lucas JR, Howard RD (1995). On alternative reproductive tactics in annurans: dynamic games with density and frequency dependence. Am Natural 146: 365-397.

Martinez JL, Moran P, Perez J, De Gaudemar B, Beall E, GarciaVazquez E (2000). Multiple paternity increases effective population size of southern Atlantic salmon populations. Mol Ecol 9: 293-298.

McGowan C, Davidson WS (1992a). Unidirectional natural hybridization between brown trout (Salmo trutta) and Atlantic salmon (Salmo salar) in Newfoundland. Can J Fish Aquat Sci 49: 117-125.

McGowan C, Davidson WS (1992b). Artificial hybridization of Newfoundland brown trout and Atlantic salmon: hatchability, survival and growth to first feeding. Aquaculture 106: 117-125.

Myers RA (1984). Demographic consequences of precocious maturation of Atlantic salmon (Salmo salar). Can J Fish Aquat Sci 41: 1349-1353.

Neat FC (2001). Male parasitic spawning in two species of triplefin blenny (Tripterigiidae): contrasts in demography, behaviour and gonadal characteristics. Environ Biol Fishes 61: 57-64.
Nicieza AG, Braña F (1995). Estructura de la poblacion reproductora, edad de maduracion y principales parametros reproductivos. In: Braña F (ed) Biologia y Conservacion del salmon Atlantico (Salmo salar) en los rios de la region cantabrica, ICONA: Madrid. pp 147-162.

Nomakuchi S, Higashi K (1996). Competitive habitat utilization in the damselfly Mnais nawai (Zygoptera: Calopterygidae) coexisting with a related species, Mnais pruinosa. Res Pop Ecol 38: $41-50$.

Olsén KH, Bjerselius R, Petersson E, Järvi T, Mayer E, Hedenskog M (2000). Lack of species-specific primer effects of odours from female Atlantic salmon, Salmo salar, and brown trout, Salmo trutta. Oikos 88: 213-220.

Pendas AM, Martinez JL, Moran P, Garcia-Vazquez E (1995). Applications of $5 \mathrm{~S}$ rDNA in Atlantic salmon, brown trout, and in Atlantic salmon $\mathrm{x}$ brown trout hybrid identification. Mol Ecol 4: 275-276.

Perez J, Martinez JL, Moran P, Beall E, Garcia-Vazquez E (1999). Identification of Atlantic salmon $\mathrm{x}$ brown trout hybrids with a nuclear marker useful for evolutionary studies. J Fish Biol 54: 460-464.

Piggins DJ (1970). Salmon x sea trout hybrids (1960-70). Ann Report Salmon Res Trust of Ireland 1970: 41-58.

Pilastro A, Bisazza A (1999). Insemination efficiency of two alternative male mating tactics in the guppy (Poecilia reticulata). Proc Roy Soc Biolog Sci Series B266: 1887-1891.

Pitcher TE, Stutchbury BJM (2000). Extraterritorial forays and male parental care in hooded warblers. Anim Behav 59: 1261-1269.

Prevost E, Chadwick EMP, Claytor RR (1992). Influence of size, winter duration and density on sexual maturation of Atlantic salmon (Salmo salar) juveniles in Little Codroy River (southwest Newfoundland). J Fish Biol 41: 1013-1019.

Refstie T, Gjedrem T (1975). Hybrids between salmonid species. Hatchability and growth rate in the fresh water period. Aquaculture 6: 333-342.

Reyes-Gavilan F, Garrido R, Nicieza AG, Toledo MM, Braña F (1996). Fish community variation along physical gradients in short streams of northern Spain and the disruptive effect of dams. Hydrobiologia 321: 155-163.

Rowe DK, Thorpe JE (1990). Differences in growth between maturing and non-maturing Atlantic salmon, Salmo salar L., parr. J Fish Biol, 36: 643-658.

Shuster SM, Sassaman C (1997). Genetic interaction between male mating strategy and sex ratio in a marine isopod. NatureLondon 388: 373-377.

Taggart JB, Hynes RA, Prodhöl PA, Ferguson A (1992). A simplified protocol for routine total DNA isolation from salmonid fishes. J Fish Biol 40: 963-965.

Thomkins JL, Simmons LW (2000). Sperm competition games played by dimorphic male beetles: fertilization gains with equal mating access. Proc Roy Soc Biolog Sci Ser B 267: 15471553.

Thorpe JE, Morgan RIG (1980). Growth rate and smolting rate of progeny of male Atlantic salmon parr, Salmo salar L. J Fish Biol17: 451-460.

Utrilla C, Lobon-Cervia J (1999). Life history patterns in a southern population of Atlantic salmon. J Fish Biol 55: 68-83.

Verspoor E (1988). Widespread hybridisation between Atlantic salmon, Salmo salar, and introduced brown trout, S. trutta, in eastern Newfoundland. I Fish Biol 32: 327-334.

Youngson AF, Knox D, Johnstone R (1992). Wild adult hybrids of Salmo salar L. and Salmo trutta L. I Fish Biol 40: 817-820.

Youngson AF, Webb JH, Thompson CE, Knox D (1993). Spawning of escaped farmed Atlantic salmon (Salmo salar): hybridization of females with brown trout (Salmo trutta). Can I Fish Aquat Sci 50: 1986-1990. 